\title{
The hawala system in Pakistan: a catalyst for money laundering \& terrorist financing
}

\begin{abstract}
The Hawala system is an alternative remittance system which channelizes underground banking and supports illicit circles to attain their reprehensible motives. This paper briefly introduces the Hawala system, status of it in connection to Pakistan, initiatives of Pakistan against hawala and concludes with final remarks.
\end{abstract}

Volume 5 Issue 4 - 2017

\author{
Muhammad Subtain Raza, Muhammad Fayyaz, \\ Haseebljaz \\ Institute of Bankers, Pakistan
}

Correspondence: Muhammad Subtain Raza, Institute of Bankers, Pakistan, Email sibtain 1232@gmail.com

Received: July 22, 2017 | Published: November 10, 2017

\section{Introduction}

The word "hawala" originatesd from the Arabic language and is known by a variety of names: hundi (a Hindi word meaning "collect"), Chiti banking (referring to the way the system operates), Chop Shop banking (China) and PoeyKuan or flying money (Thailand). El Qorchi et al., ${ }^{1} \&$ Passas $^{2}$ reported that the hawala system has been used as early as the eighth century in a number of jurisdictions and is traditionally associated with a money transfer mechanism (money transfer without actual money involvement, or any wire transfer) that operated extensively in South Asia many centuries ago, and which still exists there, as well as in the Middle East and in Africa. The term hawala system may be used on account of alternative remittance system (ARS) or informal value transfer system or underground banking, based on trust which subsists and channelizes its activities outside of or parallel to conventional banking or financial institutions. Apart from the risk-free remittance of money from expatriates, the ancient system of hawala is being used both by terrorists and money launderers to move their money to avoid detection and reporting.

\section{The hawala system: a vehicle for money laundering and terrorist financing}

Money launderers use three phases to accomplish their motives: placement, layering and integration. Since hawala is a remittance system, it can be used at any phase. There are various reasons why hawala systems may pose a money laundering and terrorist financing threat for nations. These include a lack of supervisory intents and preferences, ease of settlement across jurisdictions through already agreed value or cash outside of the banking system, the exploitation of businesses unregulated by financial regulators, the consented settlement and the jumbling of licit and illicit proceeds, and the lack of commitment and compliance to effective regulation. Before the terrorist attacks of $9 / 11$, the Hawala system was being used by the Islamic world. It is worth noting that al-Qaeda moved much of its money via the hawala system before September 11, 2001. Al-Qaeda used about a dozen trusted hawaladers, who almost certainly knew of the source and purpose of the money. Al-Qaeda also used both unwitting hawalas who probably strongly suspected that they were dealing with al-Qaeda, but were nevertheless willing to engage in the transactions.

\section{The hawala system in Pakistan}

According to UN Human Development Index, Pakistan is in the Low Human Development range, with a ranking of 146 out of 187 countries. The country is combating against two malicious menaces: money laundering and terrorist peril, which are supported by hawala. The State Bank of Pakistan (SBP) has reported that informal remittances known as Hawala/Hundi are believed to be in use for both money laundering and terrorist financing. Unfortunately, Islamic militancy, insurgency support from neighboring countries, terrorist wings of political parties, Afghan drug dealers, non-state actors and local war lords are proving themselves to be factors of instability and bloodshed in Pakistan and Hawala/Alternative remittance systems are considered the channel of ultimate lineage of monetary support for hostile insurgency from terrorist/extremists etc. Intelligence agencies have revealed the fact that funding may be channeled through money laundering processes and hawala systems. In fact, the U.S. Treasury Department's study titled "The Hawala Alternative Remittance System and Its Role in Money Laundering" 2002, identified hawala as a means of money laundering for drug trafficking and other crimes in Pakistan. Jamwal ${ }^{3}$ states that the same U.S. Treasury Department study identified Pakistan, India and Dubai on the Persian Gulf form the 'Hawala triangle' to move money secretly worldwide. Worldwide, approximately $\$ 500$ billion are remitted using this particular system and Pakistanis are involved in transacting an estimated $\$ 7$ billion through this system each year.

Terrorists occupying the Pak-Afghan border vicinities are most probably funded by using the Hawala system. They use Hawala based funding to accomplish their terrorist attacks on Pakistani army and U.S marines. Madrassas have been used as training grounds for terrorists and for terrorist funding. The possible funding from Islamic radicals is routed through the Hawala system. In Pakistan, politicians also use the alternative remittance system/hundi for their illicit gains, to dispose of their corruption-based funds and to promote terrorist attacks. The brutal carnage left behind at the Peshawar school massacre (2014), 
where 150 innocent children were murdered by Taliban, was most probably plotted and acted upon through Hawala processed funds.

\section{Actions initiated by Pakistan to curb the hawala system}

The government of Pakistan has enacted various steps to curb the exploitation of Hawala system. Under the Foreign Exchange Regulation Act Pakistan 1947, all international IVTS are illegal, because of the negative impacts of IVTS including money laundering, loss of revenue, corruption and unregulated capital flight. The State Bank of Pakistan and the Securities and Exchange Commission of Pakistan (SECP) are the country's primary financial regulators. They have established AML units to enhance financial sector oversight. The very same units are prioritizing their focus towards the control of Hawala system. SBP has pursued policies to reduce the incidence of alternative remittance systems (ARS) in Pakistan and encourage use of formal channels for remittances. The State Bank of Pakistan (2002) has focused on establishing exchange companies to bring informal moneychangers into the mainstream financial system to tighten the options to exploit ARS. According to this instruction, companies are required to register with the Securities and Exchange Commission of Pakistan and then apply to the SBP for a license to commence operations. $^{4}$

FATF special Recommendation VI suggested that the hawala system should be regulated by requiring hawaladars to obtain licenses. To meet the international standards devised by FATF and the UN, Pakistan has amended the Anti-Terrorism Act 1997, empowering law enforcement agencies to fight against terrorist financing and money laundering. In June 2004, the State Bank of Pakistan notified all hawaladars to register as authorized foreign exchange dealers and to establish minimum capital requirements. The Pakistan remittance initiative, which established exchange companies, is an integrated system for the delivery of home remittances. It empowers slaw enforcement agencies to control and regulate that particular system. Consequently, legitimate remittances from the roughly 5 million Pakistani expatriates residing abroad, sent via the hawala system prior to 2001, now flow mostly through the formal banking sector. Despite the State Bank of Pakistan's exertions, unlicensed hawala operators are still conducting their illegal dealings in parts of the country (predominantly in high profile cities like Peshawar and Karachi).

Pakistani authorities have investigated indigenous terrorist financing and money laundering, and have sought international assistance in terrorist financing matters (e.g. Dr Farooq Murder Case and Money laundering MQM Case). The local law enforcement agencies like National Accountability Bureau (NAB), the AntiNarcotics Force (ANF), the Federal Investigative Agency (FIA), and the Directorate of Customs Intelligence and Investigations (CII) are overseeing the possible use of Hawala system for money laundering, terrorist funding and other illicit gains. Currently, the National Action Plan is in process of combating the perils of corruption, terrorism, and other organized crimes primarily based on money laundering and terrorist financing. Law enforcement agencies have destroyed the networks of terrorism financiers, corrupt PEPs and criminal hawaladars. The result will be the deactivation of the exploited system of Hawala. The National Counter Terrorism Authority (NACTA) recommended to the National Action Plan committee that Iran, Saudi Arabia, and the United Arab Emirates stop funding (most of funds remitted through Hawala system) the religious groups banned in Pakistan.

Consequently, 72 organizations suspected of having connections with national and international terrorist groups have been banned in Pakistan. As per FATF Public Statement dated 27 February 2015, the FATF updated its list about "Jurisdictions no longer subject to monitoring". As a result of sound and effective measures especially against Hawala system, FATF placed Pakistan on that particular list. The FATF appreciated the Pakistan's significant progress in improving its AML/CFT regime and remarked that "Pakistan has established the legal and regulatory framework to meet its commitments in its action plan regarding the strategic deficiencies that the FATF had identified in June 2010. Pakistan is therefore no longer subject to the FATF's monitoring process under its on-going global AML/CFT compliance process. Pakistan will work with APG as it continues to address the full range of AML/CFT issues identified in its mutual evaluation report, in particular, fully implementing UNSC Resolution $1267 .{ }^{5}$

\section{Pakistan's chronological actions to combat hawalla system}

The followings is a chronological list of actions Pakistan has taken to combat directly or indirectly the Hawala system and its possible exploitation in money laundering \& terrorist financing:

a) 1997- The Anti Terrorism Act [ATA] was formulated.

b) 1999-Pakistan signed the OIC Convention on Combating International Terrorism.

c) 2002- SBP establish the exchange companies to handle the Hawala system

d) 2003- Pakistan became a signatory to the UN Convention against Corruption.

e) 2003- Pakistan effectively banned and sanctioned some NPOs and charity-based organizations.

f) 2004- State Bank of Pakistan took steps to freeze terrorist funds and to assist financial institutions to identify such funds.

g) 2004- The Anti-Terrorism Act (ATA) of 1997 was amended to extend its scope.

h) 2007- Pakistan has criminalized money laundering through the Anti-Money Laundering ordinance (AMLO). In same year Pakistan set up its Financial Intelligence Unit (FMU).

i) 2009- Money laundering was made an extraditable offence.

j) 2010- Anti-Money laundering ordinance was revised and passed as the Anti Money Laundering Act.

k) 2015- The National Action Plan was established to counter terrorism financing and related offences.

In addition to above, Government has decided to link reciprocal pacts with the United States of America (USA) and United Arab Emirates (UAE). Pakistan is a State party to 10 out of $13 \mathrm{UN}$ Conventions relating to terrorism. Pakistan has signed and ratified SAARC Regional Convention on Suppression of Terrorism and its additional protocol. Pakistan has signed and ratified the UN Convention against Illicit Traffic in Narcotic Drugs and Psychotropic 
Substances 1988 (The Vienna Convention). Pakistan is signatory to the UN Convention against Transnational Organized Crime 2000 (The Palermo Convention) and the UN Convention against Corruption (2003). Pakistan is implementing UN Security Council Resolutions against the financing of terrorism and is cooperating with the 1373 and 1267 Committees to ban terrorist organisations, to dismantle their apparatus, to choke terrorist funding and to freeze terrorist assets.

Pakistan SROs No. 773(I) 2003 and 155(I/2004) were issued in pursuance of UN Security Council Resolution Nos. 1267(1999), 1333(2000), 1373(2001), 1390(2002), 1455(2003) and 1526 (2004), whereby the directions were issued to freeze the funds and other resources of certain individuals and entities. Pakistan has signed 29 Bilateral/Multilateral Agreements with other countries regarding terrorism and Extradition Treaties with 29 countries. The sharp growth in remittances after $9 / 11$ and their persistent growth during the global financial crisis of $2007 / 08$ provide sufficient proof that remittances are channeled increasingly through formal institutions. Presently, total Pakistani remittances at about US\$ 18-20 billion per annum as against the US $\$ 15$ billion realized in FY2014. This status of remittances through formal institutions depicts the timely, effective and well managed policies of the Government of Pakistan to discourage the Hawala system, whether it is being used for legal or illegal purposes. ${ }^{6-8}$

\section{More actions needed to handle the hawala system in Pakistan}

The gravity of exploitation of the hawala system may be lessened by pursuing FATF's Recommendations 10-12 and 15, which deals with alternative remittance and contains three major elements:

a) Inclusion of persons or legal entities providing money/value transmission services by licensing or registration processes,

b) Formulation and implementation of regulations on the national and international level, and

c) Imposition of sanctions on money/value transmission services, including informal systems or networks in connection to failure of registration and noncompliance.

Taxation of Hawala networks may prove a handy tool to make it transparent and regulate the system. Governments may collect a significant amount of revenue through taxation, especially in countries like Pakistan where an estimated $\$ 7$ billion is channeled through the system each year. It is fact that malefactor terror organizations receive financial support in the pretext of Islamic education. The audit trail of funding, compulsion of opening of bank accounts and maintaining the record of inward \& outward flow of money may hinder the involvement of Hawalasystems. In a nutshell, effective regulations and supervision, awareness raising, compliance, monitoring and sanctions against malefactors of hawala systems may trim down the magnitude of money laundering and terrorist financing. For Pakistan, more efforts are required on national and international levels to curb the Hawala system operators. For this to be accomplished, an adequate budget, inter-agency arrangements, proper intelligence \& surveillance system, empowering authorities, political will, legislation and mutual cooperation agreements with international community are needed.

\section{Acknowledgments}

None.

\section{Conflicts of interest}

The author declares that there are no conflicts of interest.

\section{Funding}

None.

\section{References}

1. Qorchi M, Maimbo SM, Wilson JF. Informal Funds Transfer Systems: An Analysis of the Informal Hawala System. USA: International Monetary Fund. 2003.

2. Passas N. Informal Value Transfer Systems, Terrorism and Money Laundering: A Report to the National Institute of Justice. USA: Northeastern University. 2003;1-137.

3. Jamwal NS. Hawala-The Invisible Financing System of Terrorism. Strategic Analysis: A Monthly Journal of the IDSA. 2002;26(2):181-198.

4. The role of hawala and other similar service providers in money laundering and terrorist financing. FATF Report. USA: Thinkstock $2013 ; 1-70$

5. www.fatf-gafi.org

6. www.sbp.gov.pk

7. www.secp.gov.pk.

8. Patrick J, Sandhu HS. The Hawala Alternative Remittance System and Its Role in Money Laundering. Austria: Interpol. 2002;1-25. 